\title{
Simultaneous Biohydrogen and Bioethanol Production from Anaerobic Fermentation with Immobilized Sludge
}

\author{
Wei Han, ${ }^{1}$ Zhanqing Wang, ${ }^{1}$ Hong Chen, ${ }^{1}$ Xin Yao, ${ }^{1}$ and Yongfeng $\mathrm{Li}^{1,2}$ \\ ${ }^{1}$ School of Forestry, Northeast Forestry University, Harbin 150040, China \\ ${ }^{2}$ College of Chemistry and Chemical Engineering, Shanghai University of Engineering Science, Shanghai 200336, China
}

Correspondence should be addressed to Yongfeng Li, biohydrogen_hw@163.com

Received 17 December 2010; Accepted 9 May 2011

Academic Editor: Effie Tsakalidou

Copyright $(2011$ Wei Han et al. This is an open access article distributed under the Creative Commons Attribution License, which permits unrestricted use, distribution, and reproduction in any medium, provided the original work is properly cited.

\begin{abstract}
The effects of organic loading rates (OLRs) on fermentative productions of hydrogen and ethanol were investigated in a continuous stirred tank reactor (CSTR) with attached sludge using molasses as substrate. The CSTR reactor with attached sludge was operated under different OLRs, ranging from 8 to $24 \mathrm{~kg} / \mathrm{m}^{3} \cdot \mathrm{d}$. The $\mathrm{H}_{2}$ and ethanol production rate essentially increased with increasing OLR. The highest $\mathrm{H}_{2}$ production rate $(10.74 \mathrm{mmol} / \mathrm{h} \cdot \mathrm{L})$ and ethanol production rate $(11.72 \mathrm{mmol} / \mathrm{h} \cdot \mathrm{L})$ were obtained both operating at OLR $=24 \mathrm{~kg} / \mathrm{m}^{3} \cdot \mathrm{d}$. Linear regression results show that ethanol production rate $(y)$ and $\mathrm{H}_{2}$ production rate $(x)$ were proportionately correlated and can be expressed as $y=1.5365 x-5.054\left(r^{2}=0.9751\right)$. The best energy generation rate was $19.08 \mathrm{~kJ} / \mathrm{h} \cdot \mathrm{L}$, which occurred at OLR $=24 \mathrm{~kg} / \mathrm{m}^{3} \cdot \mathrm{d}$. In addition, the hydrogen yield was affected by the presence of ethanol and acetic acid in the liquid phase, and the maximum hydrogen production rate occurred while the ratio of ethanol to acetic acid was close to 1 .
\end{abstract}

\section{Introduction}

The negative impacts on the global environment due to the intensive use of fossil fuels need to be reduced and reversed by replacing them gradually with sustainable and carbonneutral energy carriers [1]. Ethanol can be supplemented to gasoline as a fuel for transportation and also can be used as a substrate for biodiesel production. Hence, at this moment, bioenergy technology focuses heavily on converting biomass feedstock to bioethanol and/or biodiesel [2]. Hydrogen gas is an ideal fuel source and produces no green-house gases, since it generates only water when burning [3]. Therefore, hydrogen is considered as a clean energy carrier for the future due to its high conversion, recyclability, and nonpolluting nature [4]. Fermentative hydrogen production has recently attracted increasing attention of its high rate of hydrogen evolution and its applicability to different types of organic wastes and wastewaters from industrial processes. In addition, the use of organic waste reduces waste disposal problems $[5,6]$. In addition to $\mathrm{H}_{2}$ production, anaerobic fermentation also produces a significant amount of alcohols (such as ethanol) [7].
In this study, using molasses as the sole carbon substrate, the performance of continuous $\mathrm{H}_{2}$ and ethanol production rate was investigated at different organic loading rates (OLRs) for CSTR with attached sludge. The purpose of this work was to develop two of the most critical bioenergy products, $\mathrm{H}_{2}$ and ethanol, thus, innovating dual fermentation technology.

\section{Material and Methods}

2.1. Hydrogen-Producing Sludge and Cultivation. The sludge was obtained from a secondary settling tank in a local municipal wastewater treatment plant. It was first sieved through mesh with a diameter of $0.5 \mathrm{~mm}$ in order to remove waste materials that could cause pump failure. Hydrogen productivity of the seed sludge was enhanced by aeration treatment for 30 days to inhibit the methanogenic activity prior to immobilization. The volatile suspended solid (VSS) was $17.74 \mathrm{~g} / \mathrm{L}$.

The molasses used in this study was obtained from a local beet sugar refinery (Harbin). The compositions of molasses used in this study are provided in Table 1 . The 


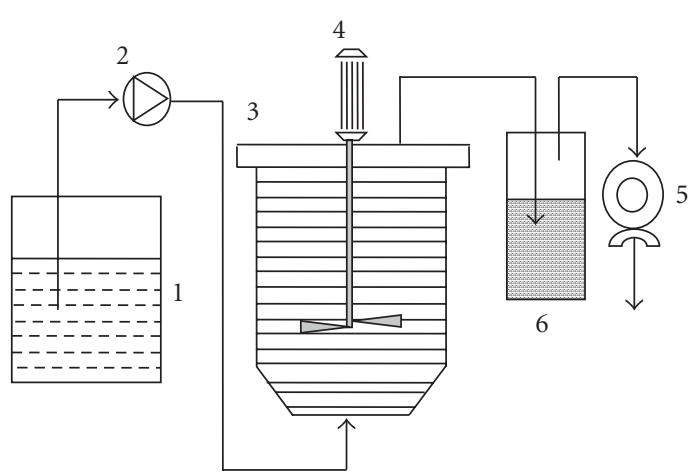
(1) Waste water box
(4) Agitator
(2) Feed pump
(3) Reactor
(5) Biogas meter
(6) Water lock

FIgURE 1: Schematic diagram of the CSTR reactor for biohydrogen production from molasses waste water.

TABLE 1: Pollution of characteristics of molasses used in this study.

\begin{tabular}{lccc}
\hline Component & $\begin{array}{r}\text { Percentage } \\
(\%, w / w)\end{array}$ & Component & $\begin{array}{r}\text { Percentage } \\
(\%, w / w)\end{array}$ \\
\hline Dried materials & $78-85$ & $\mathrm{MgO}$ & $0.01-0.1$ \\
Total sugar & $48-58$ & $\mathrm{~K}_{2} \mathrm{O}$ & $2.2-4.5$ \\
TOC & $28-34$ & $\mathrm{SiO}_{2}$ & $0.1-0.5$ \\
$\mathrm{TKN}$ & $0.2-2.8$ & $\mathrm{Al}_{2} \mathrm{O}_{3}$ & $0.05-0.06$ \\
$\mathrm{P}_{2} \mathrm{O}_{5}$ & $0.02-0.07$ & $\mathrm{Fe}_{2} \mathrm{O}_{3}$ & $0.001-0.02$ \\
$\mathrm{CaO}$ & $0.15-0.8$ & Ash content & $4-8$ \\
\hline
\end{tabular}

molasses was diluted by tap water to a COD of $10,000 \mathrm{mg} / \mathrm{L}$ and the COD: nitrogen:phosphorus ratio was maintained at $1000: 5: 1$ by the addition of synthetic fertilizer in the substrate to supply microorganisms with adequate nitrogen and phosphorus contents.

Granular activated carbon was used as a support medium for cell immobilization and retention. The particles were sieved for uniformity of approximately $1.5 \sim 2 \mathrm{~mm}$ in diameter. The main physical characteristics of granular activated carbon were offered by supplier as follows: media real density $=1420 \mathrm{~g} / \mathrm{L}$; surface area $=1200 \sim 1350 \mathrm{~m}^{2} / \mathrm{g}$; bulk density $=450 \sim 500 \mathrm{~g} / \mathrm{L}$ (Hainan Wen Chang Qiu Chi Activated Carbon. Co. Ltd.). $\mathrm{H}_{2}$-producing sludge was mixed with granular activated carbon at a volume $(\mathrm{mL})$ to weight $(\mathrm{g})$ ratio of $1: 10$. It was observed that sludge predominantly covered the surface and interior portion of the immobilized disc.

2.2. Bioreactor Operation. The bioreactor used for $\mathrm{H}_{2}$ fermentation in this study was a $12.5 \mathrm{~L}$ continuous stirred tank reactor (CSTR) with an effective volume of $5.4 \mathrm{~L}$ (Figure 1). The reactor was constructed with transparent plexiglas with a gas-liquid-solid separating device, operating in a continuous flow mode. The temperature was automatically maintained at $36^{\circ} \mathrm{C}$ by electrothermal wire. The influent flow rate was controlled by a feed pump to regulate the HRT and OLR in

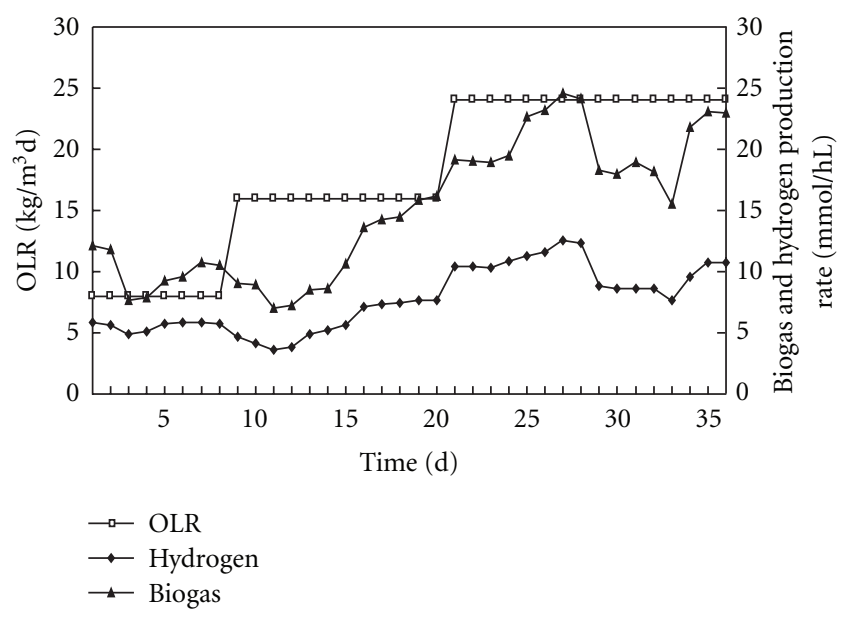

FIGURE 2: The time series of gaseous accumulation in fermentation process.

the reactor. The biogas generated was collected in a water lock and measured by a wet gas meter (Model LML-1, Changchun Filter Co., Ltd.) which was filled with an acidified saturated salt solution in order to prevent the biogas from dissolution.

2.3. Analytical Methods. The biogas yield of the CSTR was measured daily at room temperature using a wet gas meter, and its constituents $\left(\mathrm{H}_{2}\right.$ and $\left.\mathrm{CO}_{2}\right)$ were determined by gas chromatography (Model GC-122, Shanghai Anal. Inst. Co.). The gas chromatography system was equipped with a thermal conductivity detector and a stainless steel column $(2 \mathrm{~m} \times 5 \mathrm{~mm})$ filled with Porapak Q (80/100 mesh, Agilent, USA). Nitrogen was used as the carrier gas at a flow rate of $40 \mathrm{~mL} / \mathrm{min}$.

Volatile fatty acids (VFAs) and ethanol in the fermentation solution were also analyzed by gas chromatography (Model GC-112, Shanghai Analytical Apparatus Corporation, China) with a hydrogen flame ionization detector and a stainless steel column $(2 \mathrm{~m} \times 5 \mathrm{~mm})$ packed with support (GDX103, 60/80 mesh, Shanghai Maikun Chemical Co., Ltd). The operation of the stainless steel column was amenable to temperature programming within 100$200^{\circ} \mathrm{C}$. Nitrogen was used as the carrier gas at a flow rate of $50 \mathrm{~mL} / \mathrm{min}$, hydrogen as the combustion gas at $50 \mathrm{~mL} / \mathrm{min}$, and oxygen as the combustion supporting gas at $500 \mathrm{~mL} / \mathrm{min}$.

$\mathrm{COD}, \mathrm{pH}$, and ORP were measured daily in the CSTR according to standard methods [8].

\section{Results and Discussion}

3.1. $\mathrm{H}_{2}$ and Ethanol Production. The performance of $\mathrm{H}_{2}$ and ethanol (EtOH) production in CSTR is shown in Table 2. The biogas and hydrogen production rate are generally considered as important indices to evaluate the biohydrogen producing processes. Figure 2 depicts the time series of gaseous accumulations in the fermentation process. The 
TABle 2: Performance of $\mathrm{H}_{2}$ and ethanol production rate as well as energy generation rate with CSTR operated at different OLR using molasses as the carbon source.

\begin{tabular}{lcccc}
\hline $\begin{array}{l}\text { OLR } \\
\left(\mathrm{kg} / \mathrm{m}^{3} \cdot \mathrm{d}\right)\end{array}$ & $\begin{array}{c}\text { COD } \\
(\mathrm{mg} / \mathrm{L})\end{array}$ & $\begin{array}{c}\mathrm{H}_{2} \text { production rate } \\
(\mathrm{mmol} / \mathrm{h} \cdot \mathrm{l})\end{array}$ & $\begin{array}{c}\text { EtOH production rate } \\
(\mathrm{mmol} / \mathrm{h} \cdot \mathrm{l})\end{array}$ & $\begin{array}{c}\text { Energy generation rate }^{\mathrm{a}} \\
(\mathrm{kJ} / \mathrm{h} \cdot \mathrm{l})\end{array}$ \\
\hline 8 & 2000 & 5.76 & 4.23 & 7.42 \\
16 & 4000 & 7.68 & 6.04 & 10.44 \\
24 & 6000 & 10.74 & 11.72 & 19.08 \\
\hline
\end{tabular}

${ }^{\mathrm{a}}$ Energy generation rate $=\mathrm{H}_{2}$ production rate $(\mathrm{mol} / \mathrm{hL}) \times 286 \mathrm{~kJ} / \mathrm{mol} \mathrm{H} \mathrm{H}_{2}+$ EtOH production rate $(\mathrm{mol} / \mathrm{hL}) \times 1366 \mathrm{~kJ} / \mathrm{mol} \mathrm{EtOH}$.

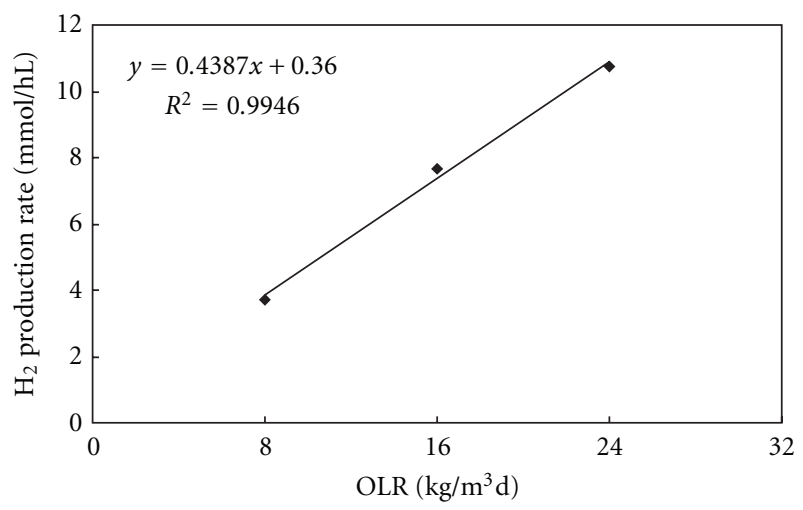

(a)

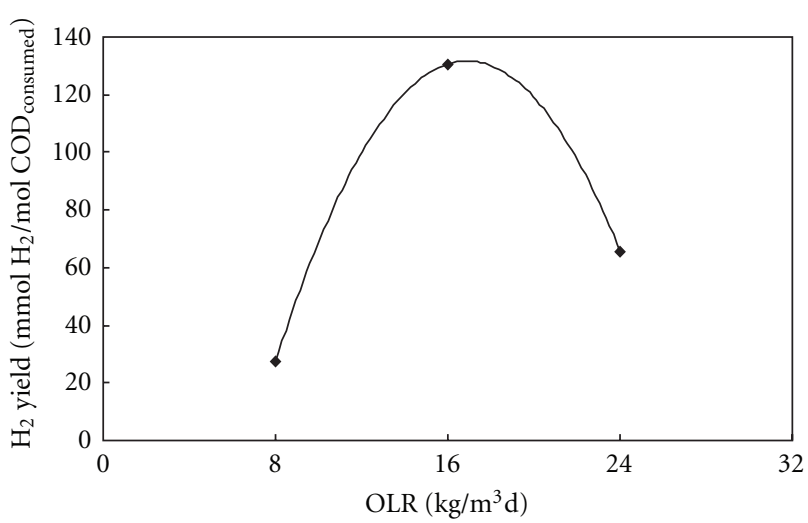

(b)

FIGURE 3: The performance of hydrogen production at different OLRs in the CSTR.

results were obtained at three different operating conditions. The differences in biogas and hydrogen production rates were attributed to the microbial population and OLR. Regardless of different OLR, the $\mathrm{H}_{2}$ and biogas production rate essentially increased with an increase in OLR as the highest OLR tested $\left(24 \mathrm{~kg} / \mathrm{m}^{3} \cdot \mathrm{d}\right)$ gave the highest $\mathrm{H}_{2}$ production rate of $10.74 \mathrm{mmol} / \mathrm{h} \cdot \mathrm{L}$ and biogas production rate of $23.02 \mathrm{mmol} / \mathrm{h} \cdot \mathrm{L}$, respectively. The highest ethanol production rate also reached $11.72 \mathrm{mmol} / \mathrm{h} \cdot \mathrm{L}$ for $\mathrm{OLR}=$ $24 \mathrm{~kg} / \mathrm{m}^{3} \cdot \mathrm{d}$.

The anterior correlation between the biofuels production could be a result of the difference in metabolisms of the sludge culture mixed bacterial population, in which $\mathrm{H}_{2}$ producing bacteria may have a different substrate of the population that tends to produce solvents (e.g., ethanol).
Figure 3(a) shows a maximum hydrogen production rate of $10.74 \mathrm{mmol} / \mathrm{h} \cdot \mathrm{L}$ at an OLR of $24 \mathrm{~kg} / \mathrm{m}^{3} \mathrm{~d}$. The hydrogen production rate was directly correlated with OLR. The correlation coefficients were greater than 0.9 . Figure $3(\mathrm{~b})$ indicates the maximum hydrogen yield by substrate consumed was $130.57 \mathrm{mmol} / \mathrm{mol}$ happened at OLR of $16 \mathrm{~kg} / \mathrm{m}^{3} \mathrm{~d}$. Based on these results, it was concluded that hydrogen production rate was enhanced with a higher OLR and hydrogen yield by substrate consumed was reduced with OLR greater than $16 \mathrm{~kg} / \mathrm{m}^{3} \mathrm{~d}$. Comparing the results of hydrogen production rate and hydrogen yield, significant differences were found at OLRs between 8 and $24 \mathrm{~kg} / \mathrm{m}^{3} \mathrm{~d}$. The hydrogen yield by substrate consumed was decreased as the OLR was greater than $16 \mathrm{~kg} / \mathrm{m}^{3} \mathrm{~d}$.

Figure 6 reveals the performance of biogas production at different OLRs in the CSTR. As evident from the figure, the variation of biogas production rate and biogas yield were similar to hydrogen production rate and hydrogen yield. Figure 6 (a) shows a maximum biogas production rate of $23.02 \mathrm{mmol} / \mathrm{h} \cdot \mathrm{L}$ at an OLR of $24 \mathrm{~kg} / \mathrm{m}^{3} \mathrm{~d}$. Linear regression results show that biogas production rate $(y)$ and OLRs $(x)$ were proportionately correlated which can be expressed as $y=0.9913 x-0.5133\left(r^{2}=0.9969\right)$. The biogas yield by substrate consumed reached $252.02 \mathrm{mmol} / \mathrm{mol}$ at OLR of $16 \mathrm{~kg} / \mathrm{m}^{3} \mathrm{~d}$ and declined to $140.7 \mathrm{mmol} / \mathrm{mol}$ at OLR of $24 \mathrm{~kg} / \mathrm{m}^{3} \mathrm{~d}$ in Figure 6(b).

3.2. Composition of Soluble Metabolites. In soluble metabolites (i.e., soluble microbial products; SMP), regardless of different OLR, the major product was ethanol, which is $38.3 \% \sim 48.9 \%$ of the total SMP. The next most abundant products were acetate and butyrate, contributing to $36.6 \%$ $41.5 \%$, and $8.4 \% \sim 21.5 \%$ of SMP, respectively. Meanwhile, a small quantity of propionate $(1.2 \% \sim 2.4)$ was also produced. This soluble metabolite composition indicates that the culture environment was favorable to $\mathrm{H}_{2}$ production, because in most efficient $\mathrm{H}_{2}$ producing system, ethanol was the predominant product.

The collection between $\mathrm{H}_{2}$ and ethanol producing pathways can also be observed from Figure 4, showing that the $\mathrm{H}_{2}$ and ethanol production rate were in general proportionately correlated irrespective of the different OLR. Linear regression results show that the correlation between ethanol production rate $(y)$ and $\mathrm{H}_{2}$ production rate $(x)$ can be expressed as $y=1.5365 x-5.054\left(r^{2}=0.9751\right)$.

3.3. Energy Production Efficiency. Since our fermentation systems produced a significant amount of gaseous and liquid 
TABLE 3: Composition of soluble metabolites during continuous fermentation with CSTR under different OLR using molasses as the carbon source.

\begin{tabular}{lcccccccc}
\hline $\begin{array}{l}\text { OLR } \\
\left(\mathrm{kg} / \mathrm{m}^{3} \cdot \mathrm{d}\right)\end{array}$ & $\begin{array}{c}\text { COD } \\
(\mathrm{mg} / \mathrm{L})\end{array}$ & $\begin{array}{c}\text { TVFA } \\
(\mathrm{mg} / \mathrm{L})\end{array}$ & $\begin{array}{c}\text { SMP } \\
(\mathrm{mg} / \mathrm{L})\end{array}$ & $\begin{array}{c}\text { HAc/SMP } \\
(\%)\end{array}$ & $\begin{array}{c}\text { HBu/SMP } \\
(\%)\end{array}$ & $\begin{array}{c}\text { HPr/SMP } \\
(\%)\end{array}$ & $\begin{array}{c}\text { EtOH/SMP } \\
(\%)\end{array}$ & $\begin{array}{c}\text { TVFA/SMP } \\
(\%)\end{array}$ \\
\hline 8 & 2000 & 579 & 941 & 36.6 & 21.5 & 2.4 & 38.4 & 61.5 \\
16 & 4000 & 721 & 1265.6 & 41.5 & 12.7 & 1.2 & 42.8 \\
24 & 6000 & 1080 & 2118 & 40.2 & 8.4 & 1.2 & 48.9 & 51 \\
\hline
\end{tabular}

HAc: acetic acid; HBu: butyric acid; HPr: propionic acid; EtOH: ethanol; TVFA (total volatile fatty acid) = HAc + HBu + HPr; SMP: soluble microbial products $(\mathrm{SMP}=\mathrm{TVFA}+\mathrm{EtOH})$.

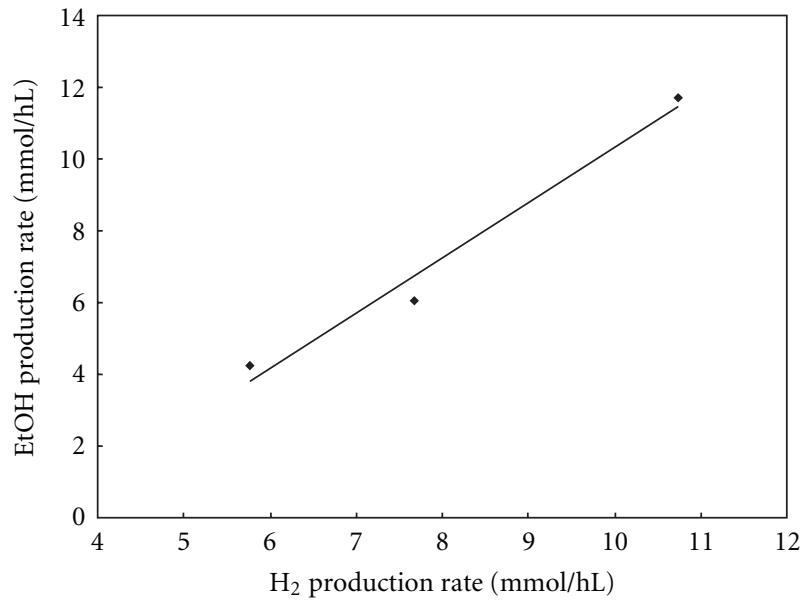

FIGURE 4: Composition of $\mathrm{H}_{2}$ and ethanol production rate in CSTR using the carbon substrate of molasses (symbols: experimental data; line: linear regression of data to indicate the trend).

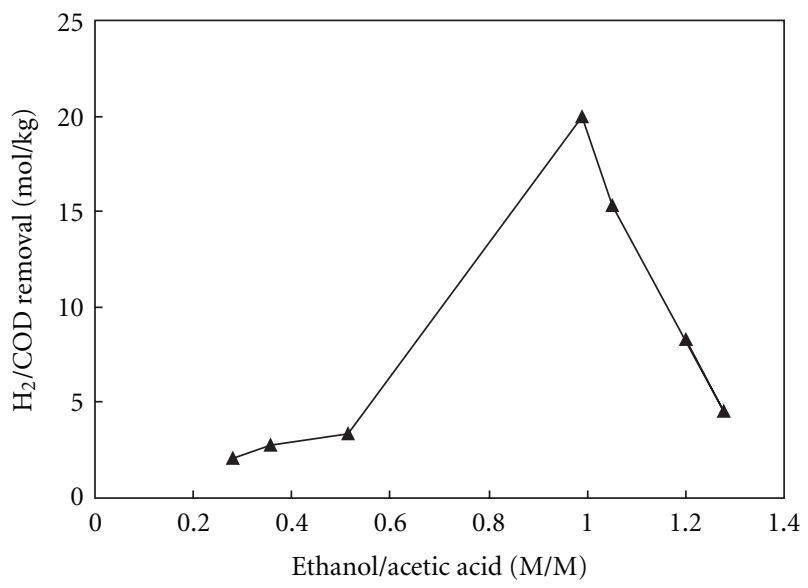

FIGURE 5: The influence of the ratio of ethanol to acetic acid on the hydrogen production rate by COD removal.

biofuels (i.e., $\mathrm{H}_{2}$ and ethanol), the process performance in terms of energy generation derived from the combination of the two biofuels was calculated according to their combustion heat values [9]. As depicted in Table 2, The energy generation rate (EGR) tended to increase as OLR increased from 8 to $24 \mathrm{~kg} / \mathrm{m}^{3} \cdot \mathrm{d}$, which is quite obvious because both $\mathrm{H}_{2}$ and ethanol production rate increased with

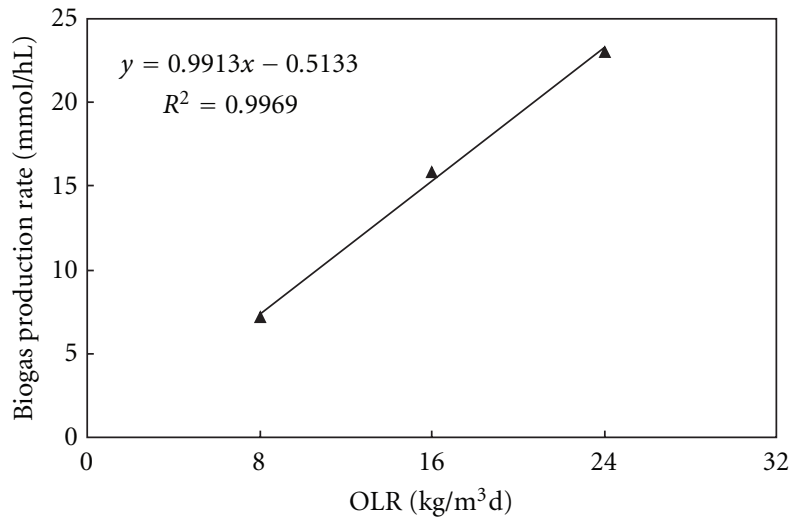

(a)

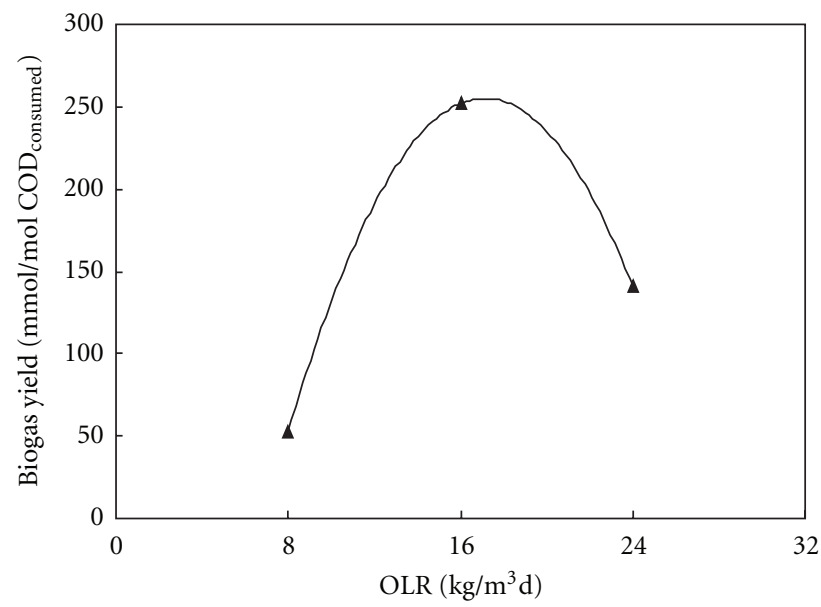

(b)

FIGURE 6: The performance of biogas production at different OLRs in the CSTR.

increasing OLR (Table 2). The maximum energy generation rate was $19.08 \mathrm{~kJ} / \mathrm{h} \cdot \mathrm{L}$, taking place when CSTR was fed with OLR at $24 \mathrm{~kg} / \mathrm{m}^{3} \mathrm{~d}$, this difference could be attributed to the variation in bacterial population structure. From the aspect of total energy generation, production of both $\mathrm{H}_{2}$ and ethanol may be superior to solely producing biofuel. Moreover, since $\mathrm{H}_{2}$ and ethanol are present in different phases, separation of the two biofuels would be relatively easy, leading to additional economical benefits arising from simple downstream processing. 
3.4. Hydrogen Production Rate and Ratio of Ethanol to Acetic. The VFAs constituents seem to have a correlation with hydrogen production, since the hydrogen production rate from COD removal ( $m o l \mathrm{H}_{2}$ produced/kg COD removal) changed with the ratio of ethanol to acetate in the hydrogen producing system. The hydrogen production rate by COD removal increased from 2 to $20 \mathrm{~mol} \mathrm{H}_{2}$ produced/kg COD removed when the ratio of ethanol to acetate was from 0 to 1 , and decreased when ratio was higher than 1 (Figure 5). This change might be related to the fermentation pathways as well as the oxidization/reduction of NADH.

\section{Conclusions}

This work demonstrated feasible bioreactor system with attached sludge for simultaneous production of $\mathrm{H}_{2}$ and ethanol as biofuels. The $\mathrm{H}_{2}$ and ethanol production rate in CSTR essentially increased with increasing OLR (from 8 $24 \mathrm{~kg} / \mathrm{m}^{3} \cdot \mathrm{d}$ ). The highest production rate of hydrogen and ethanol attained from this work was $10.74 \mathrm{mmol} / \mathrm{h} \cdot \mathrm{L}$ and $11.72 \mathrm{mmol} / \mathrm{h} \cdot \mathrm{L}$, respectively. This work also utilized energy generation rate (base on heat values of $\mathrm{H}_{2}$ and ethanol) as a performance indicator for overall energy production efficiency of the bioprocesses examined. Using molasses as substrate, the CSTR system operated at OLR $=24 \mathrm{~kg} / \mathrm{m}^{3} \cdot \mathrm{d}$ exhibited the best energy generation rate of $19.08 \mathrm{~kJ} / \mathrm{h} \cdot \mathrm{L}$. The ethanol production rate $(y)$ and $\mathrm{H}_{2}$ production rate $(x)$ were proportionately correlated and can be expressed as $y=1.5365 x-5.054\left(r^{2}=0.9751\right)$ and the maximum hydrogen production rate occurred while the ratio of ethanol to acetic acid was close to 1 .

\section{Acknowledgments}

National Hi-Tech R\&D Program (863 Program), Ministry of Science and technology, China (Grant no. 2006AA05Z109), Shanghai Science and Technology Bureau (Grant no. 071605122), Shanghai Education Committee (Grant no. 07ZZ156) and Northeast Forestry University (GRAP09), are gratefully acknowledged.

\section{References}

[1] S. Manish and R. Banerjee, "Comparison of biohydrogen production processes," International Journal of Hydrogen Energy, vol. 33, no. 1, pp. 279-286, 2008.

[2] B. E. Rittmann, "Opportunities for renewable bioenergy using microorganisms," Biotechnology \& Bioengineering, vol. 100, no. 2, pp. 203-212, 2008.

[3] N. Q. Ren, D. Y. Wang, C. P. Yang, L. U. Wang, J. L. Xu, and Y. F. Li, "Selection and isolation of hydrogen-producing fermentative bacteria with high yield and rate and its bioaugmentation process," International Journal of Hydrogen Energy, vol. 35, no. 7, pp. 2877-2882, 2010.

[4] F. R. Hawkes, R. Dinsdale, D. L. Hawkes, and I. Hussy, "Sustainable fermentative hydrogen production: challenges for process optimisation," International Journal of Hydrogen Energy, vol. 27, no. 11-12, pp. 1339-1347, 2002.

[5] Z. Qin, N. Q. Ren, J. Z. Li, and X. F. Yan, "Superacid state of acidogenic phase and control strategy for recovery," Journal of
Harbin Institute of Technology, vol. 35, no. 9, pp. 1105-1108, 2003.

[6] Y. F. Li, N. Q. Ren, Y. Chen, and G. X. Zheng, "Ecological mechanism of fermentative hydrogen production by bacteria," International Journal of Hydrogen Energy, vol. 32, no. 6, pp. 755760, 2007.

[7] Y. F. Li, The Novel Species of Fermentative $\mathrm{H}_{2}$ and Acid-Producing Bacteria and Hydrogen-Producing Engineering by Pure Culture, Ph.D. thesis, Harbin Institute of Technology, Harbin, China, 2006.

[8] APHA Standard Methods for the Examination of Water and Wastewater, American Public Health Association, NewYork, NY, USA, 19th edition, 1995.

[9] Y. Akutsu, Y. Li, H. Harada, and H. Yu, "Effects of temperature and substrate concentration on biological hydrogen production from starch," International Journal of Hydrogen Energy, vol. 34, no. 6, pp. 2558-2566, 2009. 

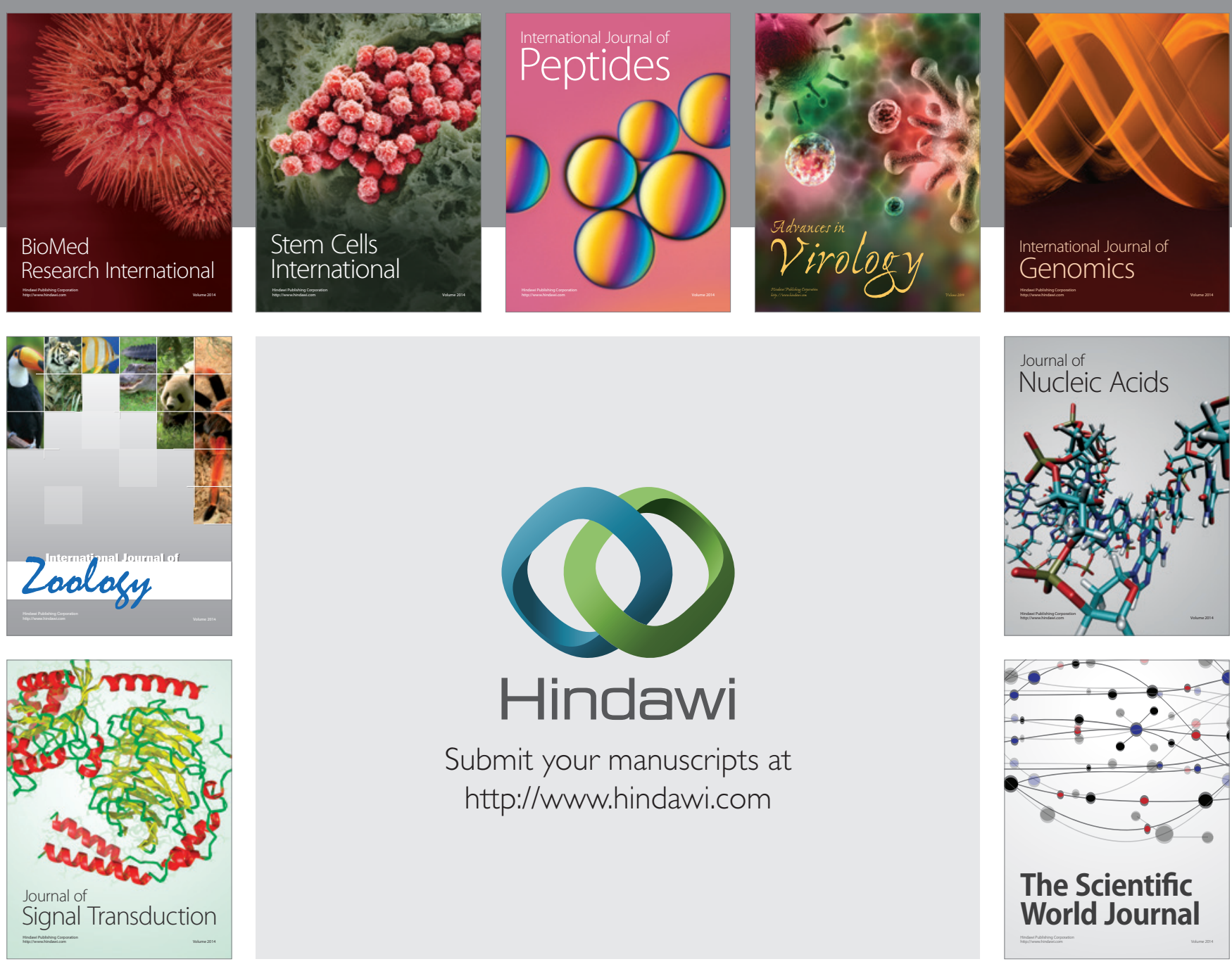

Submit your manuscripts at

http://www.hindawi.com
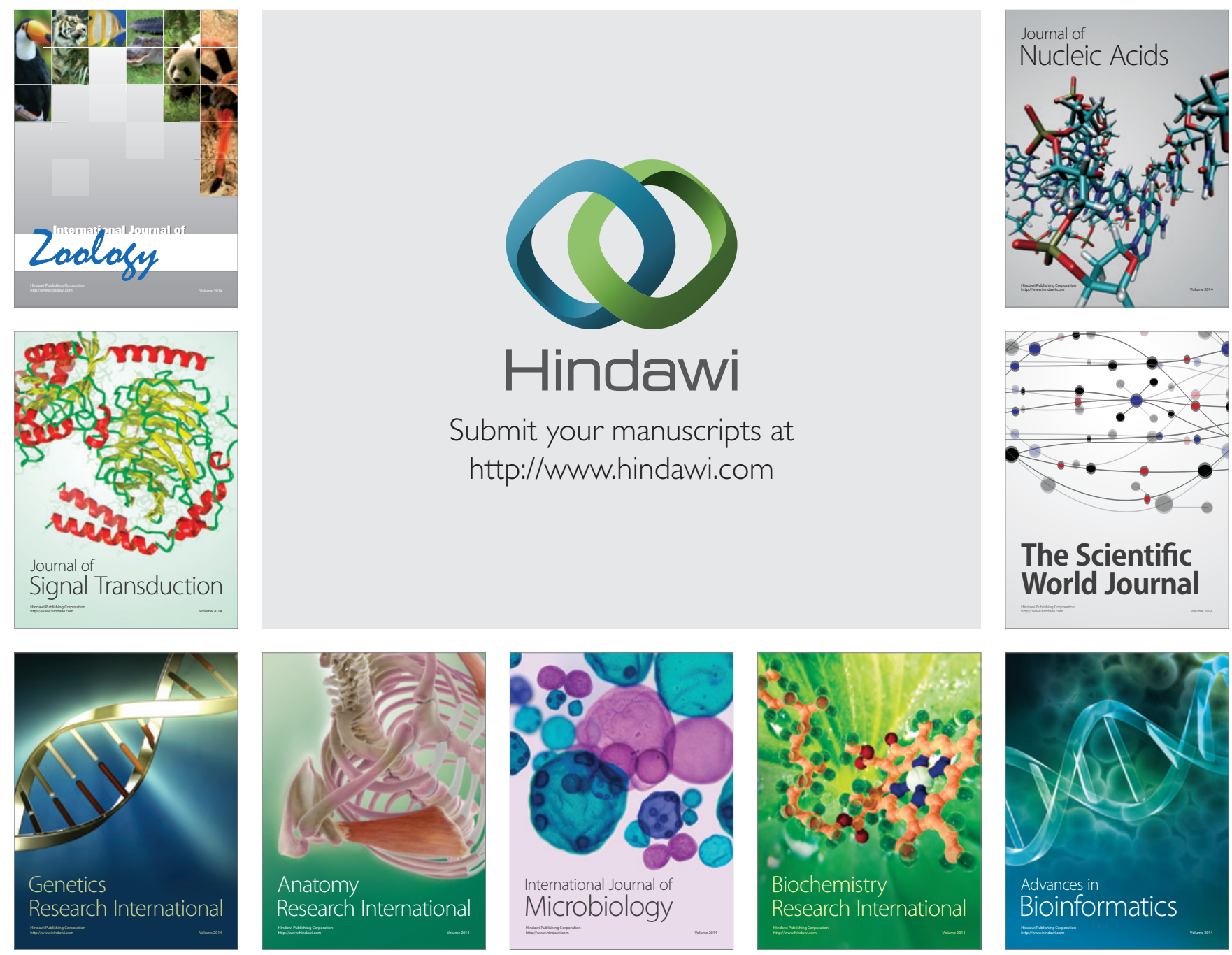

The Scientific World Journal
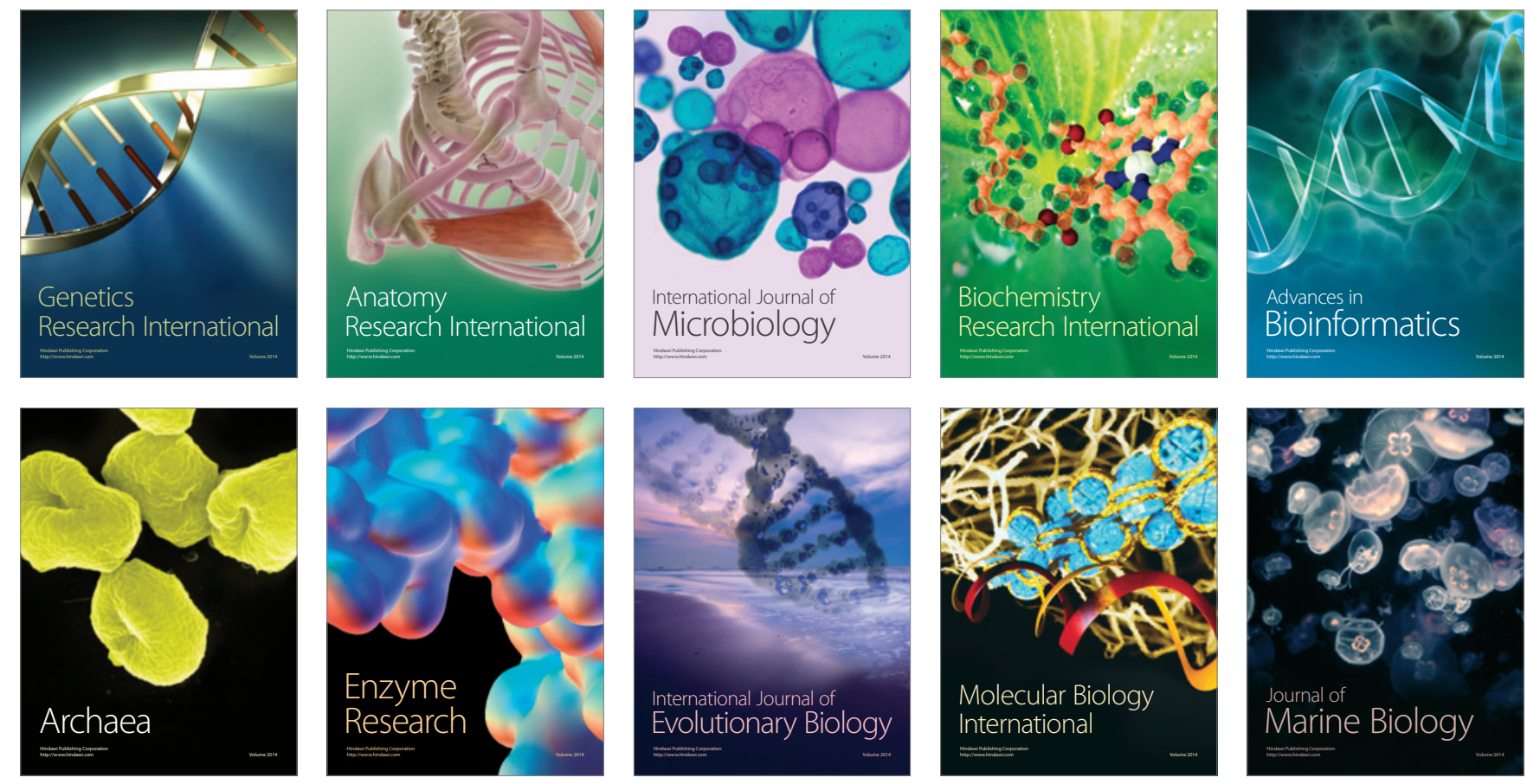